\title{
The prevalence of abnormal leukocyte count, and its predisposing factors, in patients with sickle cell disease in Saudi Arabia
}

This article was published in the following Dove Press journal:

Journal of Blood Medicine

25 October 2017

Number of times this article has been viewed

\author{
Anwar E Ahmed' \\ Yosra Z Ali ${ }^{2}$ \\ Ahmad M Al-Suliman ${ }^{3}$ \\ Jafar M Albagshi ${ }^{3}$ \\ Majid Al Salamah' \\ Mohieldin Elsayid' \\ Wala R Alanazi ${ }^{4}$ \\ Rayan A Ahmed ${ }^{5}$ \\ Donna K McClish ${ }^{6}$ \\ Hamdan AL-Jahdali ${ }^{1,2}$ \\ 'College of Public Health and Health \\ Informatics, King Saud bin Abdulaziz \\ University for Health Sciences, Riyadh, \\ Saudi Arabia; ${ }^{2}$ King Abdulaziz Medical \\ City, Riyadh, Saudi Arabia; ${ }^{3}$ King \\ Fahad Hospital, Hofuf, Saudi Arabia; \\ ${ }^{4} \mathrm{Al}-$ Maarefa College for Science and \\ Technology, Riyadh, Saudi Arabia; ${ }^{5}$ Dar \\ Al Uloom University, Riyadh, Saudi \\ Arabia; ${ }^{6}$ Department of Biostatistics, \\ Virginia Commonwealth University, \\ Richmond, VA, USA
}

Introduction: High white blood cell (WBC) count is an indicator of sickle cell disease (SCD) severity, however, there are limited studies on WBC counts in Saudi Arabian patients with SCD. The aim of this study was to estimate the prevalence of abnormal leukocyte count (either low or high) and identify factors associated with high WBC counts in a sample of Saudi patients with SCD. Methods: A cross-sectional and retrospective chart review study was carried out on 290 SCD patients who were routinely treated at King Fahad Hospital in Hofuf, Saudi Arabia. An interview was conducted to assess clinical presentations, and we reviewed patient charts to collect data on blood test parameters for the previous 6 months.

Results: Almost half (131 [45.2\%]) of the sample had abnormal leukocyte counts: low WBC counts $15(5.2 \%)$ and high $116(40 \%)$. High WBC counts were associated with shortness of breath ( $P=0.022)$, tiredness $(P=0.039)$, swelling in hands/feet $(P=0.020)$, and back pain $(P=0.007)$. The mean hemoglobin was higher in patients with normal WBC counts $(P=0.024)$, while the mean hemoglobin $\mathrm{S}$ was high in patients with high WBC counts $(P=0.003)$. After adjustment for potential confounders, predictors of high WBC counts were male gender (adjusted odds ratio $[\mathrm{aOR}]=3.63$ ) and patients with cough $(\mathrm{aOR}=2.18)$, low hemoglobin $(\mathrm{aOR}=0.76)$, and low heart rate $(\mathrm{aOR}=0.97)$. Conclusion: Abnormal leukocyte count was common: approximately five in ten Saudi SCD patients assessed in this sample. Male gender, cough, low hemoglobin, and low heart rate were associated with high WBC count. Strategies targeting high WBC count could prevent disease complication and thus could be beneficial for SCD patients.

Keywords: white blood cell, leukocyte, SCD, Saudi, hemoglobin, low heart rate, Saudi Arabia

\section{Introduction}

White blood cell (WBC) or leukocyte count is a blood test used to detect a range of blood disorders, evaluate the severity of various underlying diseases, and at times predict the risk of death. ${ }^{1-7}$ Several previous reports revealed a possible association between WBCs and severity of sickle cell disease (SCD). ${ }^{7-10}$ Buchanan and Glader ${ }^{11}$ reported that WBC counts were significantly increased during serious bacterial infection and vaso-occlusive crisis among children with SCD.

Litos et $\mathrm{al}^{10}$ found that SCD patients who developed complications had higher WBC counts than asymptomatic SCD patients. ${ }^{10} \mathrm{WBC}$ count was found to be an accurate test for detecting acute chest syndrome in SCD patients who attended an emergency department (ED) with pain crises. ${ }^{12}$ Castro et a ${ }^{13}$ noted that WBC count was associated with acute chest syndrome in patients with SCD. Liem et $\mathrm{al}^{14}$ reported SCD patients with acute chest syndrome had a higher WBC count compared to controls.
Correspondence: Anwar E Ahmed College of Public Health and Health Informatics, King Saud bin Abdulaziz University for Health Sciences, MC 2350, PO Box 22490 Riyadh, II426, Saudi Arabia

Email ahmeda5@vcu.edu 
Evidence was found that a high level of WBC count is recognized as a major risk factor for hospital admission and frequent ED visits. ${ }^{15,16}$ Olatunji and Davies ${ }^{15}$ documented that patients with particularly high levels of WBCs had frequent hospital admission. Recently, Curtis et $\mathrm{al}^{16}$ found that an elevated WBC count was associated with high risk of frequent $\mathrm{ED}$ visits.

The evidence of the association between WBC and the severity of SCD mainly comes from epidemiological studies in Western countries; however, these findings may not be generalizable to SCD patients in non-Western countries. For better understanding, the role of WBCs in SCD severity should be assessed in various SCD populations worldwide, particularly in non-Western countries.

Studies in the Eastern Province of Saudi Arabia reported high WBC counts in Saudi children with SCD and acute chest syndrome, ${ }^{17,18}$ and another study assessed SCD complications in Saudi adults with SCD, revealing high WBC levels with a mean of $12.7 \times 10^{9}$ cells $/ \mathrm{L} .{ }^{19}$ Despite clear evidence that WBC was found to be associated with complications and poor prognosis in SCD patients, no study in the Saudi SCD population has been found to assess the prevalence of high WBCs and SCD severity or complications. The purpose of the current study was to estimate the prevalence of abnormal WBCs (low or high) and identify the predictors of high WBCs in a sample of Saudis with SCD, and severity of SCD. We hypothesize that SCD symptoms and complications may be associated with high WBCs in Saudi patients with SCD.

\section{Methods}

Cross-sectional and retrospective designs were used to recruit and review medical charts of Saudi patients with SCD (age $\geq 2$ years) who attended the outpatient clinic at King Fahad Hospital in Hofuf, Eastern Region, Saudi Arabia, for routine health assessment. Four hundred SCD patients attended King Fahad Hospital in Hofuf for routine assessment during the study period between October 1, 2016 and March 31, 2017. Of those, 290 consented and enrolled in the study, with a response rate of $72.5 \%$.

The study included two stages: structured interview by a hematologist, and a chart review covering the previous 6 months for each patient. The interview took 10 to $15 \mathrm{~min}$ and the patients were asked to report whether they had fever, shortness of breath, cough, tiredness, wheezing, skin redness, swelling in hands/feet, blood transfusion, itching, and frequent $(\geq 3)$ ED visits during the previous 6 months. Participants were asked whether they experienced frequent pain in the previous 6 months. Those who responded that they "experienced frequent pain" were asked to specify the pain site: back, arm, leg, and/or chest. Participants were allowed to select more than one pain site. If the participants were aged between 2 and 17 years, pain history was assessed by the child and/or the parents.

The medical chart of each patient was reviewed for the previous 6 months. We collected data on heart rate and blood tests. The blood tests included: hemoglobin, hemoglobin F, hemoglobin A2, hemoglobin S, and the WBC count. In case of multiple readings, the most recent reading was extracted. The WBC counts were assessed by automated blood cell counters (Beckman Coulter, Brea, CA, USA) and cell counts were expressed in $10^{9}$ cells/L. In order to estimate the prevalence of abnormal leukocyte count, we categorized leukocyte count into three groups: low $<4 \times 10^{9}$ cells/L (low WBC count referred to a leukopenia), normal 4- $11 \times 10^{9}$ cells $/ \mathrm{L}$, and high $>11 \times 10^{9}$ cells $/ \mathrm{L}$ (high WBC count referred to a leukocytosis). The normal WBC range $\left(4-11 \times 10^{9}\right.$ cells/L) was applied to all age groups. For the purpose of multivariate analysis, patients with low WBC counts were excluded to identify the independent predictors of high WBC counts.

\section{Statistical analysis}

The analyses were performed using IBM SPSS Statistics for Windows, version 24 (IBM Corporation, Armonk, NY, USA). The sample characteristics were presented as percentages for non-numerical variables (Table 1) and counts and means and SDs for numerical variables (Table 2). We estimated the prevalence of abnormal leukocyte count (either low or high) using the percentage and $95 \%$ CIs. For subgroup analyses we used a chi-square test to assess the association between WBC groups and non-numerical variables (Table 1). For subgroup analyses we used the ANOVA test to assess the association between WBC groups and numerical variables (Table 2). In the adjusted analysis, we only considered high vs. normal WBC counts. Multiple-binary logistic regression was used to identify the independent factors associated with high WBC counts (Table 3). The aOR and 95\% CIs were used to assess the strength of the relationship. The significant levels criterion was $P<0.05$ in all analyses.

\section{Ethics approval}

The Ethics Committee at the Saudi Ministry of Health approved this study. All procedures performed in studies involving human participants were in accordance with the ethical standards of the institutional and/or national research committee, and with the 1964 Helsinki Declaration and its 
Table I WBC count and its relation to sample characteristics in SCD patients

\begin{tabular}{|c|c|c|c|c|c|c|c|c|}
\hline \multirow[t]{2}{*}{ Characteristics } & \multirow[t]{2}{*}{ Levels } & \multicolumn{2}{|c|}{$\begin{array}{l}\text { Overall } \\
\mathbf{N}=290\end{array}$} & \multicolumn{2}{|c|}{$\begin{array}{l}\text { Low <4 } \\
\text { I } 5(5.2 \%) \\
\end{array}$} & \multicolumn{2}{|c|}{$\begin{array}{l}\text { Normal 4-I I } \\
\text { I } 59(54.8 \%)\end{array}$} & \multirow[t]{2}{*}{$P$-value } \\
\hline & & $\mathbf{n}$ & $\%$ & $\mathbf{n}$ & $\%$ & $\mathbf{n}$ & $\%$ & \\
\hline \multirow[t]{2}{*}{ Gender } & Female & 131 & 45.2 & 7 & 5.3 & 81 & 61.8 & 0.073 \\
\hline & Male & 159 & 54.8 & 8 & 5.0 & 78 & 49.1 & \\
\hline \multirow[t]{3}{*}{ Age, years } & $<25$ & 99 & 35.1 & 5 & 5.1 & 57 & 57.6 & 0.397 \\
\hline & $25-36$ & 123 & 43.6 & 6 & 4.9 & 66 & 53.7 & \\
\hline & $>36$ & 60 & 21.3 & 2 & 3.3 & 32 & 53.3 & \\
\hline \multirow[t]{2}{*}{ Fever } & No & 133 & 46.7 & 6 & 4.5 & 78 & 58.6 & 0.573 \\
\hline & Yes & 152 & 53.3 & 9 & 5.9 & 80 & 52.6 & \\
\hline \multirow[t]{2}{*}{ Cough } & No & 152 & 52.4 & 9 & 5.9 & 91 & 59.9 & 0.105 \\
\hline & Yes & 138 & 47.6 & 6 & 4.3 & 68 & 49.3 & \\
\hline \multirow[t]{2}{*}{ Shortness of breath } & No & 152 & 52.4 & 6 & 3.9 & 95 & 62.5 & $0.022 *$ \\
\hline & Yes & 138 & 47.6 & 9 & 6.5 & 64 & 46.4 & \\
\hline \multirow[t]{2}{*}{ Wheezing } & No & 232 & 82.6 & 15 & 6.5 & 126 & 54.3 & 0.186 \\
\hline & Yes & 49 & 17.4 & 0 & 0.0 & 28 & 57.1 & \\
\hline \multirow[t]{2}{*}{ Tiredness } & No & 84 & 29.1 & 2 & 2.4 & 56 & 66.7 & $0.029 *$ \\
\hline & Yes & 205 & 70.9 & 13 & 6.3 & 103 & 50.2 & \\
\hline \multirow[t]{2}{*}{ Swelling in hands/feet } & No & 200 & 69.9 & 7 & 3.5 & 119 & 59.5 & $0.020 *$ \\
\hline & Yes & 86 & 30.1 & 8 & 9.3 & 38 & 44.2 & \\
\hline \multirow[t]{2}{*}{ Redness } & No & 253 & 87.5 & 12 & 4.7 & 140 & 55.3 & 0.661 \\
\hline & Yes & 36 & 12.5 & 3 & 8.3 & 19 & 52.8 & \\
\hline \multirow[t]{2}{*}{ Itching } & No & 208 & 72.7 & 12 & 5.8 & 118 & 56.7 & 0.292 \\
\hline & Yes & 78 & 27.3 & 3 & 3.8 & 38 & 48.7 & \\
\hline \multirow[t]{2}{*}{ Blood transfusion } & No & 196 & 67.6 & 10 & 5.1 & 104 & 53.1 & 0.651 \\
\hline & Yes & 94 & 32.4 & 5 & 5.3 & 55 & 58.5 & \\
\hline \multirow[t]{2}{*}{ Back pain } & No & 104 & 35.9 & 7 & 6.7 & 68 & 65.4 & $0.007^{*}$ \\
\hline & Yes & 186 & 64.1 & 8 & 4.3 & 91 & 48.9 & \\
\hline \multirow[t]{2}{*}{ Leg pain } & No & 72 & 24.8 & 3 & 4.2 & 32 & 44.4 & 0.075 \\
\hline & Yes & 218 & 75.2 & 12 & 5.5 & 127 & 58.3 & \\
\hline \multirow[t]{2}{*}{ Arm pain } & No & 180 & 62.1 & 9 & 5.0 & 98 & 54.4 & 0.962 \\
\hline & Yes & 110 & 37.9 & 6 & 5.5 & 61 & 55.5 & \\
\hline \multirow[t]{2}{*}{ Chest pain } & No & 176 & 60.7 & 7 & 4.0 & 101 & 57.4 & 0.372 \\
\hline & Yes & 114 & 39.3 & 8 & 7.0 & 58 & 50.9 & \\
\hline \multirow[t]{2}{*}{ Frequent ED visits } & No & 199 & 76.8 & 11 & 5.5 & 110 & 55.3 & 0.626 \\
\hline & Yes & 60 & 23.2 & 2 & 3.3 & 31 & 51.7 & \\
\hline
\end{tabular}

Note: *Significant at $\alpha=0.05$.

Abbreviations: WBC, white blood cell; SCD, sickle cell disease; ED, emergency department.

Table 2 Differences in hemoglobin electrophoresis by WBC count

\begin{tabular}{|c|c|c|c|c|c|c|c|c|c|}
\hline \multirow[t]{2}{*}{ Measure } & \multicolumn{2}{|c|}{$\begin{array}{l}\text { Overall } \\
N=290\end{array}$} & \multicolumn{2}{|c|}{$\begin{array}{l}\text { Low <4 } \\
15(5.2 \%)\end{array}$} & \multicolumn{2}{|c|}{$\begin{array}{l}\text { Normal 4-I I } \\
\text { I } 59 \text { (54.8\%) }\end{array}$} & \multicolumn{2}{|c|}{$\begin{array}{l}\text { High > I I } \\
\text { I I } 6(40 \%)\end{array}$} & \multirow[t]{2}{*}{$P$-value } \\
\hline & Mean & SD & Mean & SD & Mean & SD & Mean & SD & \\
\hline Hemoglobin & 9.2 & 1.5 & 8.7 & 1.3 & 9.4 & 1.5 & 8.9 & 1.6 & $0.024^{*}$ \\
\hline Heart rate & 84.3 & II.I & 85.6 & 10.3 & 85.1 & 11.4 & 83.2 & 10.8 & 0.383 \\
\hline Hemoglobin F & 16.3 & 6.9 & 18.8 & 7.4 & 17.3 & 7.1 & 14.5 & 6.3 & $0.001 *$ \\
\hline Hemoglobin A2 & 3.3 & 1.3 & 3.1 & 1.2 & 3.3 & 1.5 & 3.3 & I.I & 0.917 \\
\hline Hemoglobin S & 79.4 & 7.4 & 76.9 & 6.4 & 78.3 & 7.4 & 81.1 & 7.2 & $0.003 *$ \\
\hline
\end{tabular}

Note: *Significant at $\alpha=0.05$.

Abbreviation: WBC, white blood cell.

later amendments or comparable ethical standards. Informed consent was obtained from all patients included in the study. The study received ethical approval from the Saudi Ministry of Health (SMOH), Institutional Review Board Log No
15-247E. Verbal informed consent was approved by SMOH. The study research team obtained verbal consent from adult patients (age $\geq 18$ years), while verbal consent was obtained from children's parents. 
Table 3 Factors associated with high WBC count in SCD patients, N=275 (I I6 high and I59 normal)

\begin{tabular}{|c|c|c|c|c|c|c|}
\hline \multirow[t]{2}{*}{ Factor } & \multirow[t]{2}{*}{ B } & \multirow[t]{2}{*}{ SE } & \multirow[t]{2}{*}{$P$-value } & \multirow[t]{2}{*}{ aOR } & \multicolumn{2}{|c|}{ 95\% Cl for OR } \\
\hline & & & & & Lower & Upper \\
\hline Male & 1.289 & 0.363 & $0.001 *$ & 3.63 & 1.783 & 7.384 \\
\hline Age $25-36$ years & -0.418 & 0.389 & 0.283 & 0.66 & 0.307 & 1.412 \\
\hline Age $>36$ years & -0.249 & 0.435 & 0.567 & 0.78 & 0.332 & 1.829 \\
\hline Fever & 0.159 & 0.339 & 0.638 & 1.17 & 0.604 & 2.277 \\
\hline Cough & 0.779 & 0.356 & $0.029 *$ & 2.18 & 1.084 & 4.378 \\
\hline Shortness of breath & 0.025 & 0.395 & 0.949 & 1.03 & 0.473 & 2.222 \\
\hline Wheezing & -0.816 & 0.423 & 0.054 & 0.44 & 0.193 & 1.013 \\
\hline Tiredness & 0.220 & 0.396 & 0.579 & 1.25 & 0.573 & 2.708 \\
\hline Swelling in hands/feet & $0.64 I$ & 0.398 & 0.107 & 1.90 & 0.870 & 4.138 \\
\hline Redness & -0.298 & 0.503 & 0.554 & 0.74 & 0.277 & 1.989 \\
\hline Itching & 0.324 & 0.366 & 0.375 & 1.38 & 0.676 & 2.832 \\
\hline Blood transfusion & -0.426 & 0.386 & 0.270 & 0.65 & 0.307 & 1.392 \\
\hline Back pain & 0.662 & 0.361 & 0.066 & 1.94 & 0.956 & 3.930 \\
\hline Leg pain & -0.934 & 0.383 & $0.015^{*}$ & 0.39 & 0.185 & 0.833 \\
\hline Arm pain & -0.057 & 0.336 & 0.865 & 0.94 & 0.489 & 1.825 \\
\hline Chest pain & -0.110 & 0.348 & $0.75 I$ & 0.90 & 0.453 & 1.770 \\
\hline Frequent ED visits & 0.185 & 0.408 & 0.651 & 1.20 & $0.54 I$ & 2.674 \\
\hline Hemoglobin & -0.274 & 0.124 & $0.027^{*}$ & 0.76 & 0.596 & 0.969 \\
\hline Heart rate & -0.034 & 0.016 & $0.032 *$ & 0.97 & 0.936 & 0.997 \\
\hline Hemoglobin F & 0.009 & 0.037 & 0.814 & 1.01 & 0.938 & 1.084 \\
\hline Hemoglobin A2 & -0.022 & 0.128 & 0.863 & 0.98 & 0.762 & 1.256 \\
\hline Hemoglobin S & 0.034 & 0.031 & 0.273 & 1.03 & 0.973 & 1.100 \\
\hline
\end{tabular}

Note: *Significant at $\alpha=0.05$.

Abbreviations: aOR, adjusted odds ratio; $\mathrm{Cl}$, confidence interval; WBC, white blood cell; SCD, sickle cell disease; $\mathrm{ED}$, emergency department.

\section{Results}

A total of 290 SCD patients were included in the analysis. The average age of the sample was 29.1 years $( \pm \mathrm{SD}=10.2)$ and the average $\mathrm{WBC}$ count was $10.7( \pm \mathrm{SD}=6.3)$. Slightly more than half of the patients, 159 (54.8\%), were within the normal range of the leukocyte count. Abnormal leukocyte count was found in 131/290 (45.2\%; 95\% CI: $39.35 \%-51.10 \%)$, low WBC in $15 / 290(5.2 \% ; 95 \%$ CI: $2.92 \%-8.39 \%)$, and high in $116 / 290$ (40\%; $95 \% \mathrm{CI}$ : $34.32 \%-45.89 \%$ ). Of the sample, $53.3 \%$ had fever, $52.4 \%$ had shortness of breath, and $23.2 \%$ had frequent ED visits during the previous 6 months. Table 1 presents more details on the sample characteristics.

In the subgroup analyses (Table 1), the percentage of high WBC count was higher in SCD patients with shortness of breath ( $47.1 \%$ vs. $33.6 \%, P=0.022)$, tiredness $(43.4 \%$ vs. $31.0 \%, P=0.039)$, swelling in hands/feet $(46.5 \%$ vs. $37.0 \%$, $P=0.020)$, and back pain ( $46.8 \%$ vs. $27.9 \%, P=0.007)$.

Subgroup analyses in Table 2 show that the mean hemoglobin was higher in patients with normal WBC (low 8.7, normal 9.4, and high 8.9, $P=0.024$ ). The mean hemoglobin F was higher in patients with low WBC counts (low 18.8, normal 17.3, and high 14.5, $P=0.001$ ) (Figure 1). The mean hemoglobin $\mathrm{S}$ was higher in patients with high WBC counts (low 76.9, normal 78.3, and high 81.1, $P=0.003$ ) (Figure 2).

We identified multiple factors associated with high WBC counts compared to normal WBC counts (excluding low WBC counts) in Table 3. Male gender ( $\mathrm{aOR}=3.63,95 \%$ CI, $1.783-7.384)$ and patients with cough $(\mathrm{aOR}=2.18,95 \%$ CI, 1.084-4.378) increased the odds of high WBCs. However, the odds of high WBCs tended to decrease by $24 \%$ for every unit increase in hemoglobin $(\mathrm{aOR}=0.76,95 \% \mathrm{CI}$, $0.596-0.969$ ), and by $3 \%$ for every unit increase in high heart rate $(\mathrm{aOR}=0.97,95 \% \mathrm{CI}, 0.936-0.997)$.

\section{Discussion}

This epidemiological study was conducted to estimate the prevalence of abnormal leukocyte count (low or high) in a sample of Saudi patients with SCD, who were recruited from routine visits at King Fahad Hospital in Hofuf in the Eastern Province of Saudi Arabia where the prevalence of SCD was reported to be high. ${ }^{20,21}$ The study documented that high prevalence of abnormal leukocyte count was found in $131(45.2 \%)$ of our total sample: low in 15 (5.2\%), and high in $116(40 \%)$. The study estimated the mean WBC counts of $10.7 \pm 6.3($ range $=2.5-61) \times 10^{9}$ cells $/ \mathrm{L}$. This finding was 


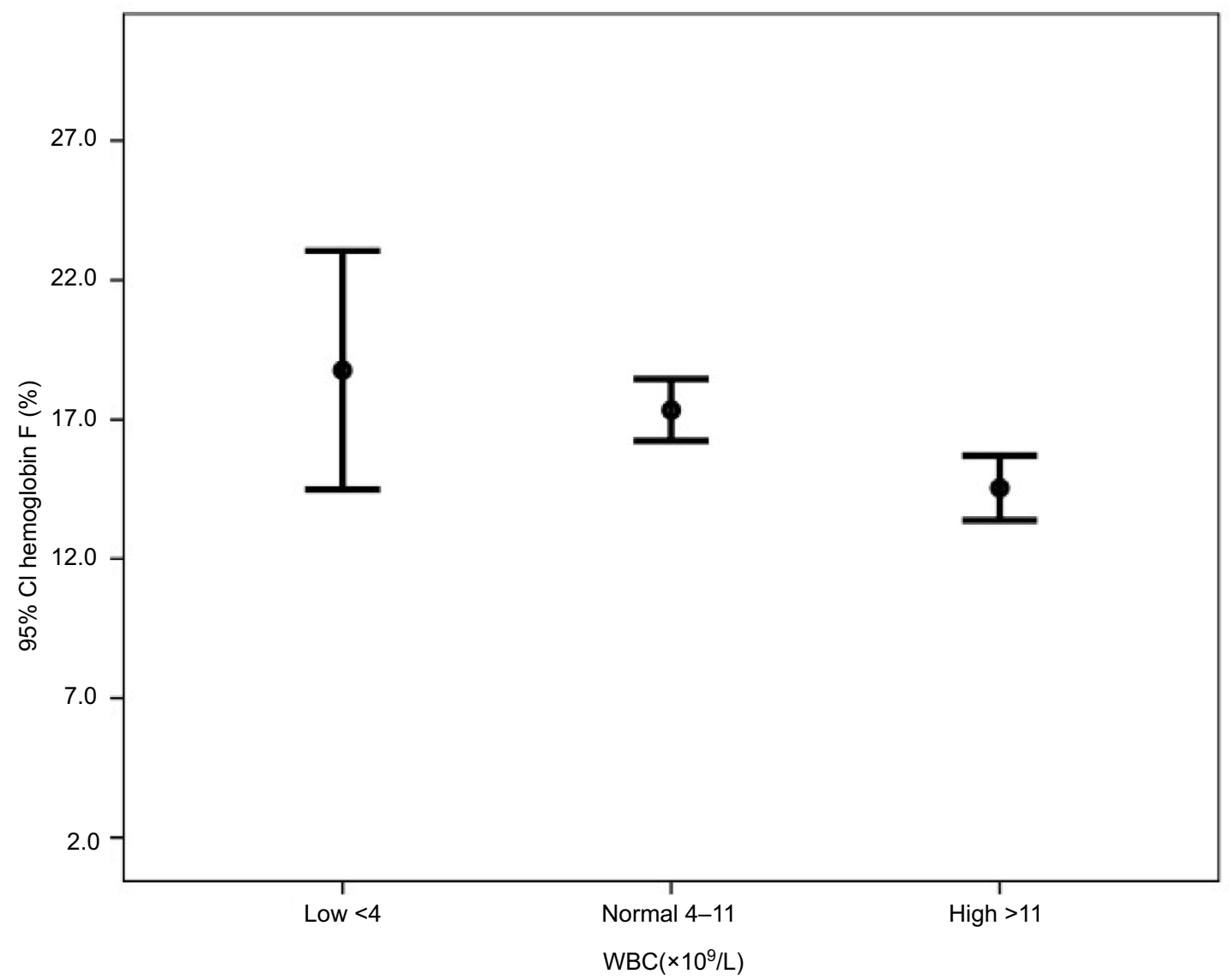

Figure I Hemoglobin F by WBC groups. Abbreviation: WBC, white blood cell.

consistent with a study conducted on Saudi adults with SCD from the Eastern Province 12.7 \pm 7.6 (range $=2.6-52.5) \times 10^{9}$ cells/L. ${ }^{19}$ However, their typical WBC value was higher than the average normal range $\left(4-11 \times 10^{9}\right.$ cells/L). The high WBC counts in the SCD population could be as a result from infections or reactions to medications. ${ }^{22,23}$ Evaluation of WBCs should be performed periodically in primary health care clinics to identify patients with lower or higher values than the normal WBC range. This may enable hematologists to assess the current medications, underlying etiology, or impending SCD crisis and initiate treatment to mitigate symptoms and modifiable factors that are associated with high WBCs.

The male gender was independently associated with high WBC counts. The odds of high WBC counts were 3.6 times higher in males compared to females $(\mathrm{aOR}=3.63)$. As per the authors' knowledge, gender's effect on high WBC counts has not been documented in SCD patients. Influence of gender on WBC counts in SCD patients should be investigated in various $\mathrm{SCD}$ populations.

The prevalence of high WBC counts differs significantly between SCD patients with a cough and those with no cough.
The odds of high WBC counts were 2 times higher in SCD patients with a cough than SCD patients with no cough. This finding is consistent with several studies..$^{24,25}$ Eisenbrown et $\mathrm{al}^{25}$ reported that a higher WBC level in SCD patients with a cough should prompt a chest X-ray.

According to subgroup analyses, there was a significant association between swelling in hands/feet and high WBC counts. Patients with swelling in hands/feet tend to have 2 times increased odds of high WBC compared to patients with no swelling in hands/feet. Several studies have shown that the presence of swelling in hands/feet in SCD patients was common, but they have not investigated its link with high WBC counts. ${ }^{26,27}$

The high prevalence of cough and swelling in hands/feet in the SCD population could be targeted in future research to identify whether they are risk factors or symptoms of high WBCs.

The current study has demonstrated that hemoglobin and heart rate are negatively associated with high risk of high WBC counts. Routine examination of hemoglobin and heart rate to monitor WBC counts may help control SCD and its symptoms. 


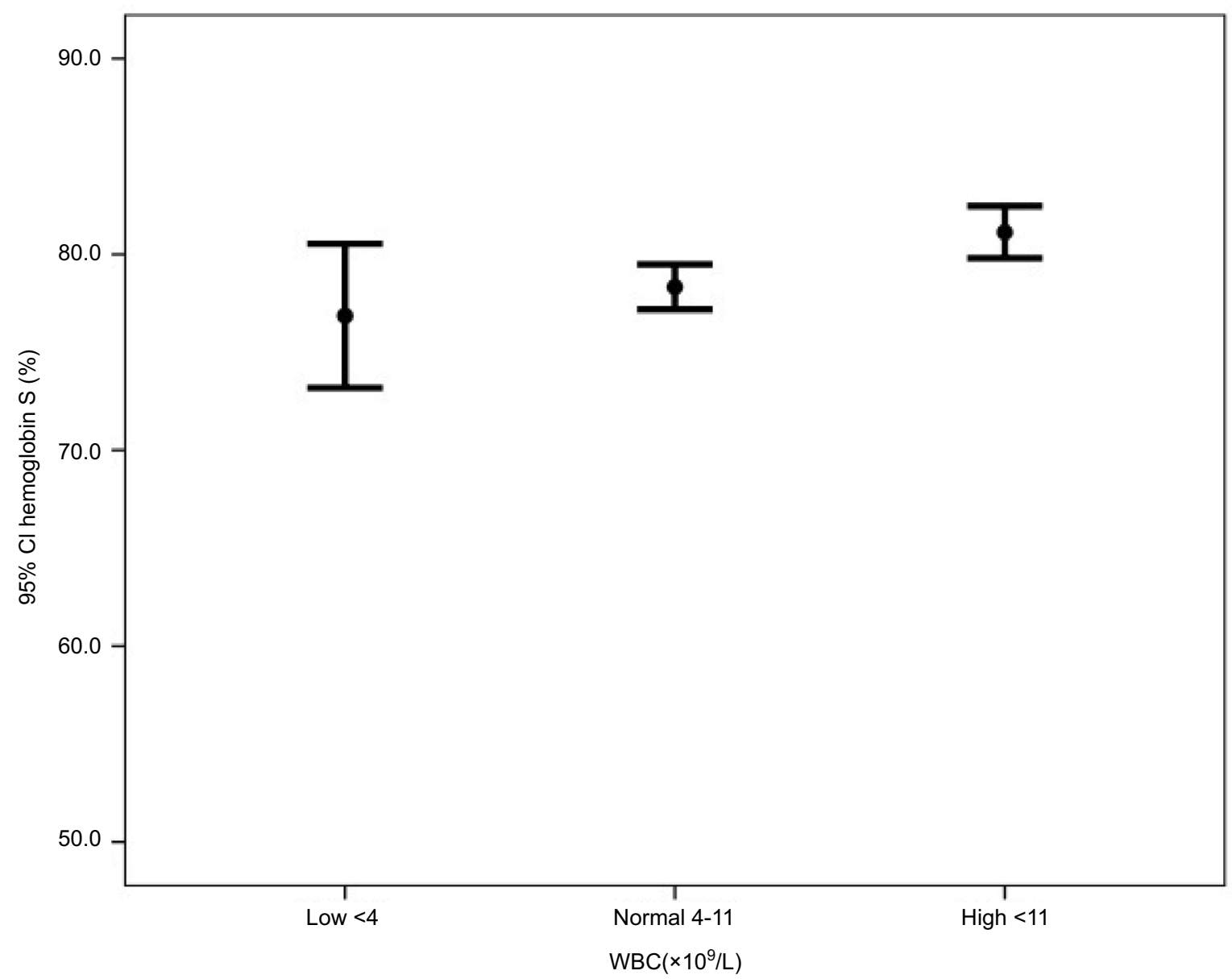

Figure 2 Hemoglobin S by WBC groups.

Abbreviation: WBC, white blood cell.

\section{Limitations}

Several limitations can be highlighted in this study. The findings of the study result from cross-sectional and retrospective chart review, thus relationships may not represent causation. The study recruited SCD patients who attended a single hospital in Saudi Arabia for routine medical check-ups, thus the population may not be a good representation of the SCD population in Saudi Arabia. Despite several limitations, the study has findings that may serve as novel evidence in identifying the potential predictors of high WBCs.

\section{Conclusion}

Abnormal leukocyte count was common: approximately five in ten Saudi SCD patients who were treated routinely at King Fahad Hospital in Hofuf. Male gender, cough, low hemoglobin, and low heart rate were associated with high WBC count. Strategies targeting high WBC count could prevent disease complication and thus be beneficial for SCD patients.

\section{Acknowledgment}

The authors would like to thank Saudi Ministry of Health for approving this study.

\section{Disclosure}

The authors report no conflicts of interest in this work.

\section{References}

1. Pocock SJ, Ashby D, Shaper AG, Walker M, Broughton PM. Diurnal variations in serum biochemical and haematological measurements. $J$ Clin Pathol. 1989;42(2):172-179.

2. Hoffman M, Blum A, Baruch R, Kaplan E, Benjamin M. Leukocytes and coronary heart disease. Atherosclerosis. 2004;172(1):1-6.

3. Madjid M, Awan I, Willerson JT, Casscells SW. Leukocyte count and coronary heart disease: implications for risk assessment. $J$ Am Coll Cardiol. 2004;44(10):1945-1956.

4. Jee SH, Park JY, Kim HS, Lee TY, Samet JM. White blood cell count and risk for all-cause, cardiovascular, and cancer mortality in a cohort of Koreans. Am J Epidemiol. 2005;162(11):1062-1069.

5. Crowell RJ, Samet JM. Invited commentary: why does the white blood cell count predict mortality? Am J Epidemiol. 1995;142(5):499-501.

6. Platt OS, Brambilla DJ, Rosse WF, Milner PF, Castro O, Steinberg MH, Klug PP. Mortality in sickle cell disease. Life expectancy and risk factors for early death. $N$ Engl J Med. 1994;330(23):1639-1644. 
7. Boggs DR, Hyde F, Srodes C. An unusual pattern of neutrophil kinetics in sickle cell anemia. Blood. 1973;41(1):59-65.

8. Okpala I. The intriguing contribution of white blood cells to sickle cell disease-a red cell disorder. Blood Rev. 2004;18(1):65-73.

9. Okpala I, Daniel Y, Haynes R, Odoemene D, Goldman J. Relationship between the clinical manifestations of sickle cell disease and the expression of adhesion molecules on white blood cells. Eur J Haematol. 2002;69(3):135-144.

10. Litos M, Sarris I, Bewley S, Seed P, Okpala I, Oteng-Ntim E. White blood cell count as a predictor of the severity of sickle cell disease during pregnancy. Eur J Obstet Gynecol Reprod Biol. 2007;133(2):169-172.

11. Buchanan GR, Glader BE. Leukocyte counts in children with sickle cell disease. Comparative values in the steady state, vaso-occlusive crisis, and bacterial infection. Am J Dis Child. 1978;132(4):396-398.

12. Naprawa JT, Bonsu BK, Goodman DG, Ranalli MA. Serum biomarkers for identifying acute chest syndrome among patients who have sickle cell disease and present to the emergency department. Pediatrics. 2005;116(3):e420-e425.

13. Castro O, Brambilla DJ, Thorington B, et al. The acute chest syndrome in sickle cell disease: incidence and risk factors. The Cooperative Study of Sickle Cell Disease. Blood. 1994;84(2):643-649.

14. Liem RI, O'Gorman MR, Brown DL. Effect of red cell exchange transfusion on plasma levels of inflammatory mediators in sickle cell patients with acute chest syndrome. Am J Hematol. 2004;76(1):19-25.

15. Olatunji PO, Davies SC. The predictive value of white cell count in assessing clinical severity of sickle cell anaemia in Afro-Caribbeans patients. Afr J Med Med Sci. 2000;29(1):27-30.

16. Curtis SA, Danda N, Etzion Z, Cohen HW, Billett HH. Elevated steady state $\mathrm{WBC}$ and platelet counts are associated with frequent emergency room use in adults with sickle cell anemia. PloS One. 2015;10(8):e0133116.

17. Al-Dabbous IA. Acute chest syndrome in sickle cell disease in Saudi Arab children in the Eastern Province. Ann Saudi Med. 2001;22(3-4):167-171.
18. Al Hawsawi ZM, Turkistani WA. Effect of hydroxyurea in children with sickle cell disease in Saudi Arabia. Journal of Taibah University Medical Sciences. 2008;3(2):129-134.

19. Alsultan A, Alabdulaali MK, Griffin PJ, et al. Sickle cell disease in Saudi Arabia: the phenotype in adults with the Arab-Indian haplotype is not benign. Br J Haematol. 2014;164(4):597-604.

20. Jastaniah W. Epidemiology of sickle cell disease in Saudi Arabia. Ann Saudi Med. 2011;31(3):289-293.

21. Al-Qurashi MM, El-Mouzan MI, Al-Herbish AS, Al-Salloum AA, Al-Omar AA. The prevalence of sickle cell disease in Saudi children and adolescents. A community-based survey. Saudi Med J. 2008;29(10):1480-1483.

22. Abramson N, Melton B. Leukocytosis: basics of clinical assessment. Am Fam Physician. 2000;62(9):2053-2060.

23. Bagul R, Chandan S, Sane VD, Patil S, Yadav D. Comparative evaluation of C-reactive protein and WBC count in fascial space infections of odontogenic origin. J Maxillofac Oral Surg. 2017;16(2): $238-242$.

24. Sadreameli SC, Reller ME, Bundy DG, Casella JF, Strouse JJ. Respiratory syncytial virus and seasonal influenza cause similar illnesses in children with sickle cell disease. Pediatr Blood Cancer. 2014;61(5):875-878.

25. Eisenbrown K, Nimmer M, Ellison AM, Simpson P, Brousseau DC. Which febrile children with sickle cell disease need a chest X-ray? Acad Emerg Med. 2016;23(11):1248-1256.

26. Berger E, Saunders N, Wang L, Friedman JN. Sickle cell disease in children: differentiating osteomyelitis from vaso-occlusive crisis. Arch Pediatr Adolesc Med. 2009;163(3):251-255.

27. Berger E, Saunders N, Wang L, Friedman JN. Sickle cell disease in children: differentiating osteomyelitis from vaso-occlusive crisis. Arch Pediatr Adolesc Med. 2009;163(3):251-255.
Journal of Blood Medicine

\section{Publish your work in this journal}

The Journal of Blood Medicine is an international, peer-reviewed, open access, online journal publishing laboratory, experimental and clinical aspects of all aspect pertaining to blood based medicine including but not limited to: Transfusion Medicine; Blood collection, Donor issues, Transmittable diseases, and Blood banking logistics; Immunohematology; Artificial and alternative

\section{Dovepress}

blood based therapeutics; Hematology; Biotechnology/nanotechnology of blood related medicine; Legal aspects of blood medicine; Historical perspectives. The manuscript management system is completely online and includes a very quick and fair peer-review system. Visit http://www.dovepress.com/ testimonials.php to read real quotes from published authors. 